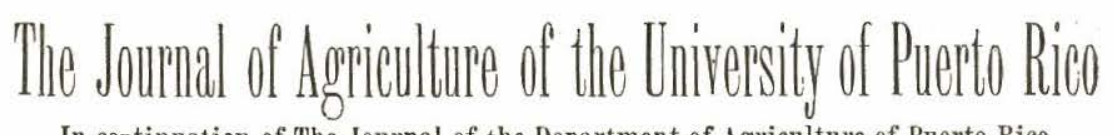

In continuation of The Journal of the Department of Agriculture of Puerto Rico

Publiahed Quarterly: January, April, July and 0ctober of each year.

Melville T. Cook, Edtor

$\begin{array}{lll}\text { VOL. XVIII OCTOBER } 1934 & \text { No } 4 .\end{array}$

\title{
INHERITANCE IN NICOTIANA. I. STUDY OF THE GLAUCOUS AND THE YELLOW CHARACTERS \\ IN $N$. TABACUM L.
}

By J. A. B. Nolla *

INTRODUCTION

Several years ago the writer became interested in some morphological characters in Nicotiana tabacum L. while making preliminary studies with relative resistance of a number of tobacco varieties to tropical diseases. This study is therefore an outgrowth of another investigation. Materials have been accumulated steadily in our collection and although our interest is primarily of a phyto. pathological nature it has been and will be our purpose to render a genetical interpretation of such morphological characters as come to our attention and which appear not to have been described or analyzed genetically up to this time. We believe that the phytopathologist will make more rapid progress in studies on immunity which may lead to the development of disease-resistant strains of our crop plants when he knows more about the general genetical behavior of his plant materials. This knowledge will eliminate to a considerable extent many of the retarding factors which enter into the picture of the control of plant diseases by the use of resistant varieties, and consequently will simplify the methods, facilitate the planning of the experiments, shorten the period of the investigations and assure more prompt results.

This short paper proposes to constitute the first of what may become a series of studies on the genetics of Nicotiana. These studies were begun at the Insular Agricultural Experiment Station of Puerto Rico in 1928 and continued in Cornell University in 1930-32 and in the University of Wisconsin in 1932-33.

\section{MATERIALS AND METHODS}

The glaucous character reported herein occurs on a Puerto Rican

* John Simon Guggenheim Memorial Foundation Fellow, Latin American Exehange. July 1932-September 1933. 
commercial tobaceo which has been known locally under the name of "Ceniza", meaning ash. The name refers to the peculiar appearance of the leaves which suggests a bluish or grayish green color. This character can be detected in the seed-bed at an early age but may be difficult to separate when seedlings are very crowded. For this reason, young seedlings should be transplanted to a second plant bed where more space will insure favorable conditions for development thereby minimizing the chances of failure in detecting the glaucous plants. Plants of this latter strain grow slower than ordinary tobaccos, the leaves are thick and the veins branch out from the midrib at an acute angle. The glaucous character appears not to have been described from any other country.

The yellow character as used here applies to a plant color which might more properly be designated as yellowish-green. This color is peculiar to normal plants at all stages of growth and is easily recognized in very young seedlings. The strain used in our studies is a pure line of a wrapper tobaceo planted by a local company prior to the year 1927 in the tobaceo districts at the higher altitudes of the island and which was believed to have descended from a single yellow plant discovered by a laborer in the back yard of his house. It is undoubtedly a mutation from a Puerto Rican variety. It was given the name of "Consolation" because it was discovered at a time when light wrappers were much in fashion among smokers and the industry here would have suffered tremendously had it not been for this timely discovery. But the advantage which the new tobacco brought to the growers was to dwindle away years later when the Consolation wrapper fell into disrepute. This yellow tobacco should not be confused with the White Burley tobaceo studied by Henika (1) from which it differs in morphological expression and in being due to a single factor whereas the latter represents a two-factor difference. It seems also to be distinct from a tobaceo variety which showed a golden color of leaves just before maturity and which was studied by Kajanus (2), who found an approximation to a genetical ratio of 15: 1 for color.

The two characters reported herein were studied in the same crosses, thereby expediting the handling of a larger number of individuals for each character. The normal yellow tobaceo is nongloucous while the "Ceniza" or glaucous, being green, serves as a contrast to yellow. Other crosses which could not be carried beyond the second generation were also made with other non-glaucons or nonyellow pure lines. 
In making counts for the yellow character it was only necessary to sow seed rather thinly in flats, then pricking out the seedlings with forceps when ten to fifteen days old. This method made possible the study of large numbers of seedlings. Another method employed was to transplant large plants from a seed-bed prepared in the usual way and making observations and counts in the field. It was soon found this method was unnecessary. In order to ascertain whether plants classified in the seed-bed as yellow or green were correctly determined, plantings of small seedlings grouped under the two classes were made in the greenhouse in one-and-a half-inch pots. Final counts made at the age of twenty-eight days, showed that the classification had been made accurately.

The separation of the glaucous or ashy seedlings was extraordinarily difficult in the seed-bed. It was found, however, that they could be detected in about a month after transplanting into small pots in the greenhouse, or into flats or beds when set at a longitudinal and transversal distance of two and one-half inches. They were transplanted into these when about two weeks old and counts could be made ten to fifteen days later. In doubtful cases the seedlings were further transplanted and kept for an additional period of two weeks when final counts were made on such individuals.

The same procedure was followed for all crosses and selfings.

In the determination of ashy or glaucous segregates the young seedlings were transplanted into flats of the usual size, transplanting thirty-five plants to each flat. The number of observations made in each progeny varied, depending upon the greenhouse and other facilities available at the time the different progenies were studied. In general, the population was fairly large.

In the season of 1928-1929 the following crosses were made: glaucous or "Ceniza" $(\mathrm{Ce}) \times$ yellow or "Consolation" (Kon); green Turkish Sansum (T) $\times$ Kon; Ce $\times \mathrm{T}$; all direct and reciprocal. The first generations of these crosses were all grown at the Insular Experiment Station of Puerto Rico in the year 1928-29 and all selfings and backerosses were then performed. The second and backeross generations were grown either at the Insular Experiment Station or in the greenhouse at Cornell University in the fall and winter of 1931; while further $\mathrm{F}_{2}$ and third generations were grown in the spring and summer of 1932 at the latter institution. Third generation progenies were also studied at the Department of Horticulture, University of Wisconsin, in the summer of 1933. 
The two characters, yellow and glaucons, are discussed separately. However, the data are from the same crosses.

In determining the significance of the genetical results given below, the probable error and Chi-square methods were employed. The probable error of numbers was determined in testing the significance of the $3: 1$ and 15:1 mendelian ratios. The expression Dev./P.E. was used as the measure of significance, taking Dev./P.E. $=3.2$, as the lower level of significance, which represents odds of 31.36 to 1 against the occurrence of a deviation as great as or greater than the designated one. Values higher than 3.2 are regarded as giving odds higher than 31.36 that the deviations are not due to random sampling. In the application of the Chi-square method for goodness of fit, values of $P$ were calculated by referring to Elderton's tables. It was considered that values of $\mathrm{P}$ equal to 0.05 or lower, indicated odds too high for such deviations to be due to random sampling.

\section{RESULTS}

\section{The Yellow Character}

The first generation of the crosses for the study of green and yellow was in all cases green, showing that the allelomorph yellow is a recessive character.

In the second generation of the direct and reciprocal crosses the seedlings were grouped into the two classes: green and yellow. From the data obtained in the $\mathrm{F}_{2}$ of the cross $C e \times K o n$ and $K o n \times C e$ a hypothesis of a single factor relation between green and yellow was formulated. The figures are given in Table I, under $\mathrm{Kon} \times \mathrm{Ce}-\mathrm{A}$ and $\mathrm{Ce} \times \mathrm{Kon}-\mathrm{A}$. In either case deviations can be attributed to random sampling.

Evidence from the Second generation.-In order to test the hy. pothesis, several $\mathrm{F}_{2}$ progenies of the above cross were studied and in addition the cross $K o n \times T$ was made. Table I contains the distribution of the $\mathrm{F}_{2}$ phenotypes in six progenies of the cross $\mathrm{Kon} \times \mathrm{Ce}$; two progenies of the reciprocal cross and the direct and reciprocal cross $K o n \times T$.

An examination of the figures shows a fairly close fit of the results to a 3:1 ratio of green to yellow seedlings. In only one progeny Kon $\times \mathrm{Ce}-\mathrm{D}$ is the deviation high enough to bring the results near the border line of significance. From the above $\mathrm{F}_{2}$ results it seems evident that the single factor difference between green and yellow is appropriate in this case. 
Evidence from the backcross.-Several of the $\mathrm{F}_{1}$ plants which were selfed for $\mathrm{F}_{2}$ studies were also backcrossed to the yellow parent. The $\mathrm{F}_{1}$ 's of the cross $K o n \times T$ were backerossed to no. 45, a yellow segregate from the cross $C e \times K o n-\mathrm{A}$, which was also recessive for the "Ceniza" character. The latter are included although the crosses had been mainly intended for the study of the $C e$ character. These backcross progenies are given in Table II. Progeny $((\mathrm{Kon} \times \mathrm{Ce})$ $\times$ Kon $)-\mathrm{B}$ shows a deviation in the distribution of green and normal seedlings which appears too high to be attributed to random sampling, the D/P.E. being 3.62. The remaining eight backeross progenies show a fairly close agreement to the expected 1:1 ratio for single-factor differences. It is, therefore, safe to conclude that on the basis of backcross results a single-factor difference exists between green and yellow.

Evidence from the $\mathrm{F}_{3}$ generation.-Further evidence in support of the single-factor pair difference for green and yellow is offered by the $\mathrm{F}_{3}$ generation. In order to secure that evidence we studied thirty-four $\mathrm{F}_{3}$ progenies of the cross $C e \times K o n$ and thirtyfour similar progenies of the reciprocal $K$ on $\times C e$. (See Tables III and IV). There should have been justification to regard all yellow segregants of the $\mathrm{F}_{2}$ as pure breeding for that character. However, in the case of the cross $C e \times K o n$, yellow segregants were carried through the third generation so that in Table III we will find ten progenies of such segregants. This was not done with the similar segregates in the cross $\mathrm{Kon} \times \mathrm{Ce}$. According to expectation the $\mathrm{F}_{3}$ progenies should show a distribution of homozygous green to heterozygous green in the ratio of $1: 2$. An examination of Table III will reveal that such expectation was very closely realized, the green $\mathrm{F}_{2}$ plants when carried through the third generation exhibiting a distribution of 8 pure-breeding green to 16 heterozygous individuals. The data in Table IV show a similar agreement with expectation; of $34 \mathrm{~F}_{3}$ progenies, 23 proved to be heterozygous and 11 homozygous for green; a close approximation to the $2: 1$ ratio.

The hypothesis of a single-factor difference is further strengthened by the individual behavior in the $\mathrm{F}_{3}$ of the heterozygous $\mathrm{F}_{2}$ plants. Of sixteen such progenies in Table III only in family 26 are the results of doubtful significance. There the Dev./P. E. is almost 3.3 and therefore the odds against such a deviation being caused by random sampling are rather high. Whether a $3: 1$ ratio prevails in that family is not established by those results. All the 23 progenies in Table IV show a fairly good agreement with the expected $3: 1$ ratio. 
From the evidence offered from $\mathrm{F}_{2}, \mathrm{~B}$.C. and $\mathrm{F}_{3}$ generations, a single-factor pair difference is established for yellow plant color as contrasted to green. It is proposed that this factor pair be designated $Y y$, green plants to be represented by $Y Y$ and yellow plants by $y y$.

\section{The Ceniza or Glaucous Character}

The plants of the first generation crosses were all normal green or non-glaucous, indicating dominance of this character over glaucous $(\mathrm{Ce})$.

In the study of the data on the $C e$ character two phenotypes were easily distinguishable, namely, the glaucous and non-glaucous and therefore individuals were classified into those two groups. The study of the distribution of the population of the second generation of the direct and reciprocal cross $C e \times K o n$ and one backeross suggested a ratio of fifteen normal green plants to one "Ceniza" or glaucous. Progeny $C e \times K o n-\mathrm{A}$ (Table V) gave 438 normal and $35 \mathrm{Ce}$ plants or a ratio of 12.51 to 1 . The significance of these results rests on the fact that on the basis of a $15: 1$ ratio, the Dev./P.E. is only 1.53. Progeny $\mathrm{Kon} \times \mathrm{Ce}-\mathrm{A}$ (Table V) showed a distribution of 128 normal to $10 \mathrm{Ce}$ plants. These numbers represent a ratio of 12.8 to 1 . On the assumption of a $15: 1$ ratio the Dev./P.E. is very low, only 0.72 . The backeross progeny $(\mathrm{Kon} \times \mathrm{C} e) \times \mathrm{Ce}$ given in Table $\mathrm{V}$ is represented by 251 normal to $66 \mathrm{Ce}$ individuals, a ratio of 3.8 to 1 . On the basis of a $3: 1$ ratio of normal to (ee the Dev./P.E. value is 2.55 and therefore such a deviation may be attributed to random sampling. The assumption of a segregation in the ratio of 15 normal to $1 C \epsilon$ in the $\mathrm{F}_{2}$ seems to be supported by a backeross ratio of 3 normal to $1 \mathrm{Ce}$. Therefore, there are sufficient grounds to assume a two factor pair difference between normal and $\mathrm{Ce}$, the $\mathrm{Ce}$ character being exhibited only as the double recessive; and dominance of one or the other, or of both factors, producing normal plants.

Evidence from the second generation.-As proof of the hypothesis of the 15: 1 relationship several $\mathrm{F}_{2}$ progenies other than those reported above, were studied. (See Table V). Of 3 progenies of $C e \times K o n$ only in B do the results appear to invalidate the hypothesis, with a Dev./P.E. reaching 3.37, slightly above the lower level of significance. But with larger numbers in $\mathrm{C}$ and $\mathrm{D}$ the results were in fairly good agreement with expectations, the Dev./P.E. being as low as 0.33 and 0.45 , respectively. Other $\mathrm{F}_{2}$ progenies which support the assumed 15: 1 ratio are $K o n \times C e-\mathrm{B}, 45 \times T$, and $T \times 45, \mathrm{~A}$ and $\mathrm{B}$, and 
$T \times C e$. All these progenies show a good agreement with the expected ratio.

Evidence from the backcrosses.-Additional evidence in support of the expected backeross ratio of $3: 1$ is furnished by progenies $(45 \times T) \times 45$ and $(T \times 45) \times 45$ which exhibit a D/P.E. of 1.48 and 1.75 , respectively, and by $(T \times C e) \times C e$ with a D/P.E. $=1.80$.

Evidence from the third generation.-If the hypothesis of duplicate genes as an explanation of the results obtained in the $\mathrm{F}_{2}$ and B.C. generations of crosses involving the study of the $C e$ character holds, it would be expected that in the third generation some progenies should be normal, some should segregate in the ratio of 15:1 and some 3:1, normal to $\mathrm{Ce}$; while one out of sixteen should be glaucous. That this expectation was realized is evidenced by the data on 20 progenies of the cross $C e \times K o n$ (Table VI) and 28 progenies of the reciprocal (Table VII). An examination of Table VI reveals that out of 20 progenies, seven segregated in the ratio of 15 to 1 , six in the ratio of $3: 1$, five were pure breeding normal and two were "Ceniza", or glaucous. In the segregating families the statistical analysis of the data proves that the results significantly support the assumption of either 15:1 or 3:1 ratios. A similar behavior is obtained in the $\mathrm{F}_{3}$ of the reciprocal cross (Table VII). There, seven progenies segregated in a ratio of 15 to 1 and six in the ratio of $3: 1$ normal to glaucous; thirteen were pure breeding normal while two were "Ceniza" or glaucous. If all the $F_{3}$ progenies are considered together the distribution is as follows: 18 progenies pure breeding normal, 14 progenies segregating in the ratio of $15: 1,12$ others in the ratio of $3: 1$, and four homozygous glaucous. If the composition of a normal plant be represented by $\mathrm{Ce}_{1} \mathrm{Ce}_{1} \mathrm{Ce}_{2} \mathrm{Ce}_{2}$, the glaucous by $\mathrm{ce}_{1} \mathrm{ce}_{1} \mathrm{ce}_{2} \mathrm{ce}_{2}$ and the hybrid in the cross by $\mathrm{Ce}_{1} \mathrm{ce}_{1} \mathrm{Ce}_{2} \mathrm{Ce}_{2}$, the following genotypes and ratios would be expected in $\mathrm{F}_{3}$ on the basis of the 15:1 hypothesis: $1 \mathrm{Ce}_{1} \mathrm{Ce}_{1} \mathrm{Ce}_{2} \mathrm{Ce}_{2}, 2 \mathrm{Ce}_{1} \mathrm{Ce}_{1} \mathrm{Ce}_{2} \mathrm{ce}_{2}, 1$ $\mathrm{Ce}_{1} \mathrm{Ce}_{1} \mathrm{ce}_{2} \mathrm{ce}_{2}, 2 \mathrm{Ce}_{1} \mathrm{ce}_{1} \mathrm{Ce}_{2} \mathrm{Ce}_{2}, 4 \mathrm{Ce}_{1} \mathrm{ce}_{1} \mathrm{Ce}_{2} \mathrm{ce}_{2}, 2 \mathrm{Ce}_{1} \mathrm{ce}_{1} \mathrm{ce}_{2}$

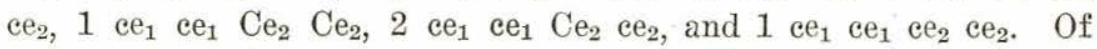
those with either one or the other factor, or both factors in the dominant condition, $\mathrm{Ce}_{1} \mathrm{ce}_{1} \mathrm{Ce}_{2} \mathrm{Ce}_{2}$ would be expected to segregate in the ratio of $15: 1, \mathrm{Ce}_{1} \mathrm{ce}_{1} \mathrm{ce}_{2} \mathrm{ce}_{2}$ and $\mathrm{ce}_{1} \mathrm{ce}_{1} \mathrm{Ce}_{2} \mathrm{ce}_{2}$ in the ratio of $3: 1$, $\mathrm{ce}_{1} \mathrm{ce}_{1} \mathrm{ce}_{2} \mathrm{ce}_{2}$ would be glancons and all the other genotypes would be pure breeding normal. There would then be expected four classes of genotypes in the following ratios: 7 pure breeding normal, 4 
segregating $15: 1,4$ segregating $3: 1$ and 1 pure recessive. When the Chi-square test for goodness of fit is applied to the expected results given above, a value of $\mathrm{P}=0.78$ is obtained.

\begin{tabular}{|c|c|c|c|c|c|}
\hline \multirow{2}{*}{ Class } & \multirow{2}{*}{$\begin{array}{c}\text { Expected } \\
\text { Ratio }\end{array}$} & \multicolumn{2}{|c|}{ Frequencies } & \multirow{2}{*}{$\frac{\mathrm{O}-\mathrm{C}^{2}}{\mathrm{C}}$} & \multirow{2}{*}{$P$} \\
\hline & & Observed & Calculated & & \\
\hline \multirow{2}{*}{ 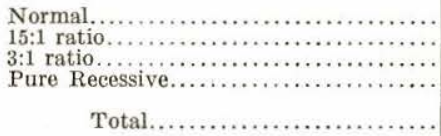 } & $\begin{array}{l}7 \\
4 \\
4 \\
1 \\
\end{array}$ & $\begin{array}{r}18 \\
14 \\
12 \\
4\end{array}$ & $\begin{array}{r}21 \\
12 \\
12 \\
3\end{array}$ & & \\
\hline & 16 & 48 & 48 & 1.09523 & 0.78046 \\
\hline
\end{tabular}

The deviations from the expected ratio of the distribution of the $\mathrm{F}_{3}$ families are such as might be expected by chance alone eleven times in twenty trials and it may be concluded, therefore, that the results obtained support the suggested hypothesis of duplicate genes.

On the basis of $F_{2}$, B.C. and $\mathrm{F}_{3}$ results it is concluded that the assumption of a 2-factor difference for the $C e$ character is justified. These factors are designated as $C e_{1}$ and $C e_{2}$ with their corresponding allelomorphs $c e_{1}$ and $c e_{2}$. The presence of either factor in the dominant condition produces normal plants while both factors must be recessive to produce the "Ceniza" character. The constitution of a "Ceniza" plant will be represented by $c e_{1} c e_{1} c e_{2} c e_{2}$.

\section{Independent Inheritance}

It was of interest to determine from the data whether there existed any linkage relations between the factor pair $\mathrm{Yy}$ and $C e_{1} c e_{1}$ or $\mathrm{Ce}_{2} \mathrm{Ce}_{2}$. The fact that $N$. tabacum has twenty-four pairs of chromosomes would make the detection of linkage between those factors of unique interest especially since the occurrence of the mutants has been reported from Puerto Rico simultaneously. From the analysis of the distribution of the phenotypes in three $\mathrm{F}_{2}$ progenies, twelve $\mathrm{F}_{3}$ 's and one backeross progeny it appears that no linkage exists between the factor pairs $C e_{1} c e_{1}$ and $C e_{2} c e_{2}$ and yellow (Yy). The reader is referred to Table VIII. The $\mathrm{F}_{2}$ progenies $\mathrm{Ce} \times \mathrm{Kon}$ $-\mathrm{C}$ and $-\mathrm{D}$ and $\mathrm{Kon} \times \mathrm{Ce}-\mathrm{A}$, on the basis of independent inheritance of the characters should yield four classes in the following ratios: 45 normal green, 15 normal yellow, $3 \mathrm{Ce}$ green and $1 \mathrm{Ce}$ yellow. The Chi-square method of testing the goodness of fit showed that for $C e \times K o n-C, \mathrm{P}=0.53$; for $C e \times K o n-\mathrm{D}, \mathrm{P}=0.80$ and $K o n \times C e-\mathrm{A}, \mathrm{P}=0.52$. These values of $\mathrm{P}$ all show that the deviations from the expected are not significant. 
In the $\mathrm{F}_{3}$ of the direct and reciprocal crosses of $C e \times K o n$, progenies $6,7,52,67,68$ and 76 , segregating in the ratio of 3 normal to $1 \mathrm{Ce}$ and 3 green to 1 yellow, should show a distribution of phenotypes as follows: nine normal green, 3 normal yellow, $3 \mathrm{Ce}$ green and $1 \mathrm{Ce}$ yellow. These expectations are realized in all these progenies (see Table VIII). In all these progenies the values of $\mathrm{P}$ are high, the lowest being 0.13 for family no. 68. This value, however, indicates that the deviations might be expected to be due to chance alone, once in eight times.

Progenies $30,55,62,66,71$ and 85 which segregated in the ratio of 15 normal to $1 \mathrm{Ce}$ and 3 green to 1 yellow, would be expected to show the phenotypes in the same ratios as the $\mathrm{F}_{2}$ progenies, namely $45: 15: 3: 1$. Such expectation is fully accomplished in all the progenies except no. 55. An examination of the distribution of the phenotypes in that progeny, however, shows that the deficiencies may not be attributed to linkage.

The distribution of the genotypes in the $\mathrm{F}_{3}$ generation is given in Table IX. The normal expectation of genotypes on the basis of a 15: 1 ratio for the $C e$ character and 3:1 segregation for green and yellow is as follows. Green genotypes to give only, 7 normal; 4 segregating in the ratio of 15 normal to $1 \mathrm{Ce} ; 4$ in the ratio of 3 normal to $1 \mathrm{Ce}$; and 1 pure breeding "Ceniza". Those green individuals of the composition $Y y$ should show the following distribution: 14 normal, 8 segregating 15 normal to $1 \mathrm{Ce}$, 8 segregating into 3 normal and $1 \mathrm{Ce}$, and 2 pure breeding $\mathrm{Ce}$. The yellow genotypes are not analyzed in the above table, but the expectation would be the same as for pure breeding greens.

A consideration of the results given in Table IX shows that the deviations from the expected ratio are such as ean well be attributed to conditions of the experiment.

The results of $\mathrm{F}_{2}$ and $\mathrm{F}_{3}$ progenies given in support of the hypothesis of the independent inheritance of the Yy and $C e_{1} c e_{1} C e_{2} c e_{2}$ are further complemented by the backcross results.

So, from the above results it may safely be concluded that no linkage exists between the factor for yellow plant color and those factors responsible for the "Ceniza" or glaucous character.

\section{ACKNOWLEDGMENTS}

The writer gratefully acknowledges his indebtedness to Hon. C. E. Chardon, Commissioner of Agriculture of Puerto Rico at the time this work was begun, for his cooperation and interest; to Prof. R. 


\section{APPENDIX}

TABLE I

SEGREGATION OF THE GREEN (Y) AND YELLOW (y) CHARACTERS IN THE $\mathrm{F}_{2} \mathrm{OF}^{\mathrm{N}}$ CROSSES BETWEEN VARIOUS PURE LINES OF TOBACCO

\begin{tabular}{|c|c|c|c|c|c|c|c|}
\hline \multirow[b]{2}{*}{ Progeny } & \multirow{2}{*}{ Color } & \multirow[b]{2}{*}{$\mathrm{n}$} & \multicolumn{2}{|c|}{ Frequencies } & \multirow[b]{2}{*}{ Dev. } & \multirow[b]{2}{*}{ P. E. } & \multirow[b]{2}{*}{ D/P.E } \\
\hline & & & Observed & $\begin{array}{c}\text { Calculated } \\
(3: 1)\end{array}$ & & & \\
\hline Kon $\mathrm{x} \mathrm{Ce}-\mathrm{A} \ldots \ldots \ldots$ & $\begin{array}{l}\text { Green } \ldots . . . \\
\text { Yellow.... }\end{array}$ & 461 & $\begin{array}{l}359 \\
102\end{array}$ & $\begin{array}{l}345.75 \\
115.25\end{array}$ & 13.25 & 6.27 & 2.11 \\
\hline Kon $\mathrm{x} \mathrm{Ce}-\mathrm{B} \ldots \ldots \ldots$ & $\begin{array}{l}\text { Green...... } \\
\text { Yellow.... }\end{array}$ & 1995 & $\begin{array}{r}1489 \\
506\end{array}$ & $\begin{array}{r}1496.25 \\
498.75\end{array}$ & 7.25 & 13.08 & 0.55 \\
\hline Kon $\mathrm{x} \mathrm{Ce}-\mathrm{C} \ldots \ldots \ldots$ & $\begin{array}{l}\text { Green..... } \\
\text { Yellow.... }\end{array}$ & 400 & $\begin{array}{r}297 \\
103\end{array}$ & $\begin{array}{l}300.00 \\
100.00\end{array}$ & 3.00 & 5.84 & 0.51 \\
\hline Kon $\mathrm{x} \mathrm{Ce}-\mathrm{D} \ldots . . .$. & $\begin{array}{l}\text { Green..... } \\
\text { Yellow.... }\end{array}$ & 912 & $\begin{array}{l}656 \\
256\end{array}$ & $\begin{array}{l}684.00 \\
228.00\end{array}$ & 28.00 & 8.82 & 3.17 \\
\hline $\mathrm{Kon} \mathrm{x} \mathrm{Ce}-\mathrm{E} \ldots \ldots \ldots \ldots$ & $\begin{array}{l}\text { Green...... } \\
\text { Yellow.... }\end{array}$ & 824 & $\begin{array}{l}638 \\
186\end{array}$ & $\begin{array}{l}618.00 \\
206.00\end{array}$ & 20.00 & 8.38 & 2.39 \\
\hline $\mathrm{K}$ on $\mathrm{x} \mathrm{Ce}-\mathrm{F} \ldots \ldots \ldots$ & $\begin{array}{l}\text { Green...... } \\
\text { Yellow.... }\end{array}$ & 713 & $\begin{array}{l}536 \\
177\end{array}$ & $\begin{array}{l}534.75 \\
178.25\end{array}$ & 1.25 & 7.80 & 0.16 \\
\hline $\mathrm{Ce} \mathrm{x}$ Kon-A............ & $\begin{array}{l}\text { Green...... } \\
\text { Yellow.... }\end{array}$ & 1150 & $\begin{array}{l}856 \\
294\end{array}$ & $\begin{array}{l}862.50 \\
287.50\end{array}$ & 6.50 & 9.90 & 0.66 \\
\hline $\mathrm{Ce} \times \mathrm{K}$ on $-\mathrm{B} . . . . .$. & $\begin{array}{l}\text { Green...... } \\
\text { Yellow.... }\end{array}$ & 358 & $\begin{array}{r}279 \\
79\end{array}$ & $\begin{array}{r}268.50 \\
89.50\end{array}$ & 10.50 & 5.53 & 1.89 \\
\hline Kon $\mathrm{x} \mathrm{T}-\mathrm{A} \ldots \ldots \ldots \ldots$ & $\begin{array}{l}\text { Green...... } \\
\text { Yellow.... }\end{array}$ & 4642 & $\begin{array}{l}3522 \\
1120\end{array}$ & $\begin{array}{l}3481.50 \\
1160.50\end{array}$ & 40.50 & 19.90 & 2.04 \\
\hline $\mathrm{T} \times \mathrm{K}$ Kn $-\mathrm{B} \ldots \ldots \ldots$ & $\begin{array}{l}\text { Green...... } \\
\text { Yellow.... }\end{array}$ & 5156 & $\begin{array}{l}3844 \\
1312\end{array}$ & $\begin{array}{l}3867.00 \\
1289.00\end{array}$ & 23.00 & 20.97 & 1.10 \\
\hline
\end{tabular}


454 THE JOURNAL OF AGRICULTURE OF THE UNIVERSITY OF P. $R$.

TABLE II

SEGREGATION OF THE GREEN (Y) AND YELLOW (y) CHARACTERS IN THE BACKCR OSS GENERATION OF CROSSES BETWEEN VARIOUS PURE LINES OF TOBACCO

\begin{tabular}{|c|c|c|c|c|c|c|c|}
\hline \multirow{2}{*}{ Progeny } & \multirow{2}{*}{ Color } & \multirow{2}{*}{$\mathrm{n}$} & \multicolumn{2}{|c|}{ Frequencies } & \multirow{2}{*}{ Dev. } & \multirow[b]{2}{*}{ P. E. } & \multirow[b]{2}{*}{ D/P. E. } \\
\hline & & & Observed & $\begin{array}{c}\text { Calculated } \\
(1: 1)\end{array}$ & & & \\
\hline$(\mathrm{Kon} \times \mathrm{Ce}) \times \mathrm{Kon}-\mathrm{A}$. & $\begin{array}{l}\text { Green...... } \\
\text { Yellow.... }\end{array}$ & 1797 & $\begin{array}{l}869 \\
928\end{array}$ & $\begin{array}{l}898.50 \\
898.50\end{array}$ & 29.50 & 14.29 & 2.06 \\
\hline$(\mathrm{Kon} \times \mathrm{Ce}) \times \mathrm{Kon}-\mathrm{B}$. & $\begin{array}{l}\text { Green...... } \\
\text { Yellow.... }\end{array}$ & 730 & $\begin{array}{l}398 \\
332\end{array}$ & $\begin{array}{l}365.00 \\
365.00\end{array}$ & 33.00 & 9.11 & 3.62 \\
\hline$(\mathrm{Kon} \times \mathrm{Ce}) \times \mathrm{Kon}-\mathrm{C}$. & $\begin{array}{l}\text { Green...... } \\
\text { Yellow.... }\end{array}$ & 974 & $\begin{array}{l}490 \\
484\end{array}$ & $\begin{array}{l}487.00 \\
487.00 \\
\end{array}$ & 3.00 & 10.53 & 0.28 \\
\hline$(\mathrm{K} o n \times \mathrm{Ce}) \times \mathrm{K}$ on-D. & $\begin{array}{l}\text { Green...... } \\
\text { Yellow.... }\end{array}$ & 141 & $\begin{array}{l}64 \\
77\end{array}$ & $\begin{array}{l}70.50 \\
70.50\end{array}$ & 6.50 & 4.00 & 1.62 \\
\hline$(\mathrm{K} o n \times \mathrm{Ce}) \times \mathrm{Kon}-\mathrm{E}$. & $\begin{array}{l}\text { Green...... } \\
\text { Yellow.... }\end{array}$ & 367 & $\begin{array}{l}184 \\
183\end{array}$ & $\begin{array}{l}183.50 \\
183.50\end{array}$ & 0.50 & 6.46 & 0.08 \\
\hline (Ce x Kon) x Kon-A. & $\begin{array}{l}\text { Green...... } \\
\text { Yellow.... }\end{array}$ & 154 & $\begin{array}{l}80 \\
74\end{array}$ & $\begin{array}{l}77.00 \\
77.00\end{array}$ & 3.00 & 4.19 & 0.72 \\
\hline (Ce $\times$ Kon) $\times$ Kon $-B$. & $\begin{array}{l}\text { Green...... } \\
\text { Yellow.... }\end{array}$ & 362 & $\begin{array}{l}191 \\
171 \\
\end{array}$ & $\begin{array}{l}18100 \\
181.00 \\
\end{array}$ & 10.00 & 6.42 & 1.56 \\
\hline$($ Kon $x T) \times 43 \ldots$ & $\begin{array}{l}\text { Green...... } \\
\text { Yellow.... }\end{array}$ & 911 & $\begin{array}{l}460 \\
451\end{array}$ & $\begin{array}{l}455.50 \\
455.50\end{array}$ & 4.50 & 10.18 & 0.44 \\
\hline $\mathrm{T} \times \mathrm{K}$ on) $\mathrm{x} 43 \ldots$ & $\begin{array}{l}\text { Green...... } \\
\text { Yellow.... }\end{array}$ & 1187 & $\begin{array}{l}589 \\
598\end{array}$ & $\begin{array}{l}593.50 \\
593.50\end{array}$ & 4.50 & 11.62 & 0.36 \\
\hline
\end{tabular}


A. Emerson, Head of the Department of Plant Breeding at Cornell University, Prof. James G. Moore, Chairman of the Department of Horticulture at the University of Wisconsin, and Prof. James Johnson, Tobaceo Pathologist at Wisconsin, for generously placing at the writer's disposal the equipment in their laboratories and helping in the field operations. To Professors Emerson and Johnson as well as to Prof. John H. Parker of Kansas State College, and Prof. A. C. Fraser of Cornell, he is also indebted for valuable criticisms and encouragement. Finally, his acknowledgments are due to The John Simon Guggenheim Memorial Foundation of New York for the fellowship which made the conclusion of these studies possible.

\section{SUMMARY}

1. Two previously undescribed characters of $N$. tabacum are described and studied genetically. The yellow plant color appears to be distinct from similar deficiencies heretofore reported. It is not to be confused with the Burley character in White Burley tobacco.

2. Green color is dominant to yellow color.

3. Normal green is dominant to glaucous or "Ceniza".

4. Green and yellow are differentiated by a single factor pair which is designated $Y y$.

5. Normal green and $C e$ or glaucaus plants are differentiated by two factor pairs; therefore segregation occurs in the proportion of 15 normal green to 1 glaucous $(\mathrm{Ce})$. These are designated by $\mathrm{Ce}_{1}$ $c e_{1} \mathrm{Ce}_{2} \mathrm{Ce}_{2}$.

6. The factors for glancous and for yellow are inherited independently of each other.

Department of Agriculture and Commerce, San Juan, Puerto Rico.

\section{LITERATURE CITED}

(1) Henika, F. S. The inheritance of the White Burley character in tobaceo. Jour. Agr. Res. 44:477-493, fig. 1. 1932.

(2) Kajanus, B. Über eine Kreuzung zwischen grunblättrigem und gelbblättrigem Tabak. Hereditas 5:84-86. 1924. 
TABLE III

RESULTS OF THE F GENERATION OF THE CROSS Ce $\times$ Kon IN THE STUDY OF THE Y'ELLOW CHARACTER

\begin{tabular}{|c|c|c|c|c|c|c|c|}
\hline \multirow[b]{2}{*}{ Progeny } & \multirow[b]{2}{*}{ Color } & \multirow[b]{2}{*}{$\mathrm{n}$} & \multicolumn{2}{|c|}{ Frequencies } & \multirow[b]{2}{*}{ Dev. } & \multirow[b]{2}{*}{ P. E. } & \multirow[b]{2}{*}{ D/P. E. } \\
\hline & & & Observed & $\begin{array}{c}\text { Calculated } \\
(3: 1)\end{array}$ & & & \\
\hline $2 \ldots \ldots \ldots \ldots \ldots$ & $\begin{array}{l}\text { Green...... } \\
\text { Yellow.... }\end{array}$ & 996 & $\begin{array}{l}776 \\
220\end{array}$ & $\begin{array}{l}747.00 \\
249.00\end{array}$ & 29.00 & 9.22 & 3.15 \\
\hline $4 \ldots \ldots \ldots \ldots \ldots \ldots \ldots \ldots$ & $\begin{array}{l}\text { Green...... } \\
\text { Yellow.... }\end{array}$ & 920 & $\begin{array}{l}708 \\
212\end{array}$ & $\begin{array}{l}690.00 \\
230.00\end{array}$ & 18.00 & 8.86 & 2.03 \\
\hline $6 \ldots \ldots \ldots \ldots \ldots \ldots \ldots \ldots$ & $\begin{array}{l}\text { Green...... } \\
\text { Yellow.... }\end{array}$ & 1135 & $\begin{array}{l}876 \\
259\end{array}$ & $\begin{array}{l}851.25 \\
283.75\end{array}$ & 24.75 & 9.84 & 2.52 \\
\hline $7 \ldots \ldots \ldots \ldots \ldots \ldots \ldots \ldots$ & $\begin{array}{l}\text { Green....... } \\
\text { Yellow.... }\end{array}$ & 470 & $\begin{array}{l}359 \\
111\end{array}$ & $\begin{array}{l}352.50 \\
117.50\end{array}$ & 6.50 & 6.33 & 1.03 \\
\hline $8 \ldots \ldots \ldots \ldots \ldots \ldots \ldots \ldots$ & $\begin{array}{l}\text { Green...... } \\
\text { Yellow.... }\end{array}$ & 483 & $\begin{array}{l}373 \\
110\end{array}$ & $\begin{array}{l}36225 \\
120.75\end{array}$ & 10.75 & 6.42 & 1.67 \\
\hline $10 \ldots \ldots \ldots \ldots \ldots \ldots \ldots$ & $\begin{array}{l}\text { Green...... } \\
\text { Yellow.... }\end{array}$ & 144 & $\begin{array}{r}115 \\
29\end{array}$ & $\begin{array}{r}108.00 \\
36.00\end{array}$ & 7.00 & 3.50 & 200 \\
\hline $13, \ldots \ldots \ldots \ldots \ldots \ldots \ldots \ldots$ & $\begin{array}{l}\text { Green...... } \\
\text { Yellow.... }\end{array}$ & 517 & $\begin{array}{l}393 \\
124\end{array}$ & $\begin{array}{l}387.75 \\
129.25\end{array}$ & 5.25 & 6.64 & 0.79 \\
\hline $21 \ldots \ldots \ldots \ldots \ldots \ldots \ldots \ldots$ & $\begin{array}{l}\text { Green...... } \\
\text { Yellow.... }\end{array}$ & 1353 & $\begin{array}{r}1033 \\
320\end{array}$ & $\begin{array}{r}1014.75 \\
338.25\end{array}$ & 18.25 & 10.71 & 1.70 \\
\hline $25 \ldots \ldots \ldots \ldots \ldots \ldots \ldots \ldots \ldots \ldots$ & $\begin{array}{l}\text { Green...... } \\
\text { Yellow.... }\end{array}$ & 158 & $\begin{array}{r}120 \\
38\end{array}$ & $\begin{array}{r}118.50 \\
39.50\end{array}$ & 1.50 & 3.67 & 0.41 \\
\hline $26 \ldots \ldots \ldots \ldots \ldots \ldots \ldots$ & $\begin{array}{l}\text { Green....... } \\
\text { Yellow.... }\end{array}$ & 689 & $\begin{array}{l}542 \\
147\end{array}$ & $\begin{array}{l}516.75 \\
172.25\end{array}$ & 25.25 & 7.67 & 3.29 \\
\hline $31 \ldots \ldots \ldots \ldots \ldots \ldots \ldots$ & $\begin{array}{l}\text { Green....... } \\
\text { Yellow.... }\end{array}$ & 459 & $\begin{array}{r}363 \\
96\end{array}$ & $\begin{array}{l}344.25 \\
114.75\end{array}$ & 18.75 & 6.26 & 2.99 \\
\hline $32 \ldots \ldots \ldots \ldots$ & $\begin{array}{l}\text { Green....... } \\
\text { Yellow.... }\end{array}$ & 333 & $\begin{array}{r}241 \\
92\end{array}$ & $\begin{array}{r}249.75 \\
83.25\end{array}$ & 8.75 & 5.33 & 1.64 \\
\hline $33 . \ldots \ldots \ldots \ldots \ldots \ldots \ldots$ & $\begin{array}{l}\text { Green...... } \\
\text { Yellow.... }\end{array}$ & 1250 & $\begin{array}{l}966 \\
284\end{array}$ & $\begin{array}{l}937.50 \\
312.50\end{array}$ & 28.50 & 10.30 & 2.77 \\
\hline $34 \ldots \ldots \ldots \ldots \ldots \ldots \ldots \ldots$ & $\begin{array}{l}\text { Green...... } \\
\text { Yellow.... }\end{array}$ & 202 & $\begin{array}{r}150 \\
52\end{array}$ & $\begin{array}{r}151.50 \\
50.50\end{array}$ & 1.50 & 4.15 & 0.36 \\
\hline $44 \ldots \ldots \ldots \ldots \ldots \ldots \ldots \ldots$ & $\begin{array}{l}\text { Green....... } \\
\text { Yellow.... }\end{array}$ & 406 & $\begin{array}{r}315 \\
91\end{array}$ & $\begin{array}{l}304.50 \\
101.50\end{array}$ & 10.50 & 5.88 & 1.79 \\
\hline $46 \ldots \ldots \ldots \ldots \ldots \ldots \ldots \ldots \ldots$ & $\begin{array}{l}\text { Green..... } \\
\text { Yellow.... }\end{array}$ & 751 & $\begin{array}{l}560 \\
191\end{array}$ & $\begin{array}{l}563.25 \\
187.75\end{array}$ & 3.25 & 8.00 & 0.41 \\
\hline
\end{tabular}

Families breeding true to green: $1,5,9,14,20,23,45$ and 47 .

Families breeding true to yellow: $15,16,1718,19,39,40,41,42$ and 43 
456 THE JOURNAL OF AGRICULTURE OF THE UNIVERSTTY OF P. R.

TABLE IV

BEHAVIOR OF THE $F_{3}$ GENERATION OF THE CROSS $K o n \times C e$ IN THE STUDY OF

THE YELLOW CHARACTER

\begin{tabular}{|c|c|c|c|c|c|c|c|}
\hline \multirow{2}{*}{ Progeny } & \multirow{2}{*}{ Color } & \multirow{2}{*}{$n$} & \multicolumn{2}{|c|}{ Frequencies } & \multirow{2}{*}{ Dev. } & \multirow{2}{*}{ P. E. } & \multirow{2}{*}{$\mathrm{D}_{l} \mathrm{P} . \mathrm{E}$. } \\
\hline & & & Observed & $\begin{array}{c}\text { Calculated } \\
(3: 1)\end{array}$ & & & \\
\hline $52 \ldots \ldots \ldots$ & $\begin{array}{l}\text { Green..... } \\
\text { Yellow.... }\end{array}$ & 585 & $\begin{array}{l}445 \\
140\end{array}$ & $\begin{array}{l}438.75 \\
146.25 \\
\end{array}$ & 6.25 & 7.06 & 0.89 \\
\hline $54 \ldots \ldots \ldots \ldots$ & $\begin{array}{l}\text { Green..... } \\
\text { Yellow.... }\end{array}$ & 376 & $\begin{array}{r}291 \\
85 \\
\end{array}$ & $\begin{array}{r}282.00 \\
94.00\end{array}$ & 9.00 & 5.66 & 1.59 \\
\hline $55 \ldots \ldots \ldots \ldots \ldots \ldots \ldots \ldots$ & $\begin{array}{l}\text { Green...... } \\
\text { Yellow.... }\end{array}$ & 1016 & $\begin{array}{l}772 \\
244 \\
\end{array}$ & $\begin{array}{l}762.00 \\
254.00 \\
\end{array}$ & 10.00 & 9.31 & 1.07 \\
\hline $56 \ldots \ldots \ldots \ldots \ldots \ldots \ldots$ & $\begin{array}{l}\text { Green..... } \\
\text { Yellow.... }\end{array}$ & 492 & $\begin{array}{l}373 \\
119 \\
\end{array}$ & $\begin{array}{l}369.00 \\
123.00\end{array}$ & 4.00 & 6.48 & 0.62 \\
\hline $61 \ldots \ldots \ldots$ & $\begin{array}{l}\text { Green..... } \\
\text { Yellow... }\end{array}$ & 761 & $\begin{array}{l}566 \\
195 \\
\end{array}$ & $\begin{array}{l}570.75 \\
190.25 \\
\end{array}$ & 475 & 8.06 & 0.59 \\
\hline $62 \ldots$ & $\begin{array}{l}\text { Green..... } \\
\text { Yellow.... }\end{array}$ & 759 & $\begin{array}{l}570 \\
189 \\
\end{array}$ & $\begin{array}{l}569.25 \\
189.75 \\
\end{array}$ & 0.75 & 8.05 & 0.09 \\
\hline $63 \ldots \ldots \ldots \ldots$ & $\begin{array}{l}\text { Green .... } \\
\text { Yellow.... }\end{array}$ & 439 & $\begin{array}{l}335 \\
104 \\
\end{array}$ & $\begin{array}{l}329.25 \\
109.75 \\
\end{array}$ & 5.75 & 6.12 & 0.94 \\
\hline $66 \ldots$ & $\begin{array}{l}\text { Green..... } \\
\text { Yellow... } \\
\end{array}$ & 452 & $\begin{array}{l}339 \\
113 \\
\end{array}$ & $\begin{array}{l}339.00 \\
113.00 \\
\end{array}$ & 0 & 6.21 & 0 \\
\hline $67 \ldots \ldots$ & $\begin{array}{l}\text { Green .... } \\
\text { Yellow.... } \\
\end{array}$ & 405 & $\begin{array}{l}302 \\
103 \\
\end{array}$ & $\begin{array}{l}303.75 \\
101.25 \\
\end{array}$ & 1.75 & 5.88 & 0.30 \\
\hline $68 \ldots$ & $\begin{array}{l}\text { Green..... } \\
\text { Yellow.... }\end{array}$ & 416 & $\begin{array}{r}318 \\
98 \\
\end{array}$ & $\begin{array}{l}312.00 \\
104.00 \\
\end{array}$ & 6.00 & 5.96 & 1.01 \\
\hline $69 \ldots \ldots$. & $\begin{array}{l}\text { Green ..... } \\
\text { Yellow.... }\end{array}$ & 497 & $\begin{array}{l}375 \\
122\end{array}$ & $\begin{array}{l}372.75 \\
124.25 \\
\end{array}$ & 2.75 & 6.51 & 0.42 \\
\hline $70 \ldots \ldots \ldots \ldots \ldots \ldots \ldots$ & $\begin{array}{l}\text { Green..... } \\
\text { Yellow. ... } \\
\end{array}$ & 435 & $\begin{array}{l}332 \\
103 \\
\end{array}$ & $\begin{array}{l}326.25 \\
108.75 \\
\end{array}$ & 5.75 & 6.09 & 0.94 \\
\hline $71 \ldots \ldots \ldots$ & $\begin{array}{l}\text { Green...... } \\
\text { Yellow.... }\end{array}$ & 325 & $\begin{array}{r}253 \\
72 \\
\end{array}$ & $\begin{array}{r}243.75 \\
81.25 \\
\end{array}$ & 9.25 & 5.27 & 1.76 \\
\hline $72 \ldots$ & $\begin{array}{l}\text { Green ..... } \\
\text { Yellow.... }\end{array}$ & 213 & $\begin{array}{r}153 \\
60 \\
\end{array}$ & $\begin{array}{r}159.75 \\
53.25 \\
\end{array}$ & 6.75 & 4.26 & 1.58 \\
\hline $76 \ldots \ldots$ & $\begin{array}{l}\text { Green..... } \\
\text { Yellow... }\end{array}$ & 208 & $\begin{array}{r}154 \\
54 \\
\end{array}$ & $\begin{array}{r}156.00 \\
52.00\end{array}$ & 2.00 & 4.21 & 0.48 \\
\hline $77 \ldots$ & $\begin{array}{l}\text { Green..... } \\
\text { Yellow.... }\end{array}$ & 208 & $\begin{array}{r}155 \\
53 \\
\end{array}$ & $\begin{array}{r}156.00 \\
52.00 \\
\end{array}$ & 1.00 & 4.21 & 0.24 \\
\hline $79 \ldots$ & $\begin{array}{l}\text { Green..... } \\
\text { Yellow... } \\
\end{array}$ & 260 & $\begin{array}{r}202 \\
58 \\
\end{array}$ & $\begin{array}{r}195.00 \\
65.00 \\
\end{array}$ & 7.00 & 4.71 & 1.49 \\
\hline $85 \ldots$ & $\begin{array}{l}\text { Green..... } \\
\text { Yellow.... }\end{array}$ & 360 & $\begin{array}{r}270 \\
90 \\
\end{array}$ & $\begin{array}{r}27000 \\
90.00 \\
\end{array}$ & 0 & 5.54 & 0 \\
\hline $87 \ldots$ & $\begin{array}{l}\text { Green..... } \\
\text { Yellow.... }\end{array}$ & 359 & $\begin{array}{r}284 \\
75 \\
\end{array}$ & $\begin{array}{r}269.25 \\
89.75 \\
\end{array}$ & 14.75 & 5.53 & 2.67 \\
\hline $88 \ldots$ & $\begin{array}{l}\text { Green...... } \\
\text { Yellow.... }\end{array}$ & 248 & $\begin{array}{r}191 \\
57 \\
\end{array}$ & $\begin{array}{r}186.00 \\
62.00 \\
\end{array}$ & 5.00 & 4.60 & 1.09 \\
\hline $89 \ldots \ldots \ldots$ & $\begin{array}{l}\text { Green ..... } \\
\text { Yellow.... }\end{array}$ & 266 & $\begin{array}{r}210 \\
56 \\
\end{array}$ & $\begin{array}{r}199.50 \\
66.50 \\
\end{array}$ & 10.50 & 4.76 & 2.20 \\
\hline $90 \ldots \ldots \ldots$ & $\begin{array}{l}\text { Green..... } \\
\text { Yellow... } \\
\end{array}$ & 549 & $\begin{array}{l}423 \\
121 \\
\end{array}$ & $\begin{array}{l}411.75 \\
137.25 \\
\end{array}$ & 16.25 & $\begin{array}{r}6.84 \\
\\
\end{array}$ & 2,38 \\
\hline $91 .$. & $\begin{array}{l}\text { Green..... } \\
\text { Yellow.... }\end{array}$ & 196 & $\begin{array}{r}149 \\
47\end{array}$ & $\begin{array}{r}147.00 \\
49.00\end{array}$ & 2.00 & 4.09 & 0.49 \\
\hline
\end{tabular}

Families bree ing true to green: $53,57,58,59,60,64,65,74,78,81$ and 83 . 
TABLE V

SEGREGATION OF THE CENIZA (ce) OR GLAUCOUS CHARACTER AND THE NORMAL CHARACTER (Ce) IN THE SECOND AND BACKCROSS

GENERATIONS OF CROSSES

\begin{tabular}{|c|c|c|c|c|c|c|c|c|}
\hline \multirow{3}{*}{ Progeny } & \multirow{3}{*}{ Color } & \multirow{3}{*}{$\mathrm{n}$} & \multicolumn{3}{|c|}{ Frequencies } & \multirow{3}{*}{ Dev. } & \multirow{3}{*}{ P. E. } & \multirow{3}{*}{ D/P. E. } \\
\hline & & & \multirow{2}{*}{ Observed } & \multicolumn{2}{|c|}{ Calculated } & & & \\
\hline & & & & $\mathrm{n}$ & ratio & & & \\
\hline Ce $x$ Kon-A........ & $\begin{array}{l}\text { Normal.... } \\
\text { Ceniza.... }\end{array}$ & 473 & $\begin{array}{r}438 \\
35\end{array}$ & $\begin{array}{r}443.44 \\
29.56\end{array}$ & $15: 1$ & 5.44 & 3.55 & 1.53 \\
\hline Ce $\mathrm{x}$ Kon-B...... & $\begin{array}{l}\text { Normal.... } \\
\text { Ceniza.... }\end{array}$ & 451 & $\begin{array}{r}411 \\
40\end{array}$ & $\begin{array}{r}422.71 \\
28.29\end{array}$ & $15: 1$ & 11.71 & 3.47 & 3.37 \\
\hline Ce $x$ Kon-C........ & $\begin{array}{l}\text { Normal... } \\
\text { Ceniza..... }\end{array}$ & 997 & $\begin{array}{r}933 \\
64 \\
\end{array}$ & $\begin{array}{r}934.69 \\
62.31 \\
\end{array}$ & $15: 1$ & 1.69 & 5.16 & 0.33 \\
\hline Ce $\mathrm{x}$ Kon-D...... & $\begin{array}{l}\text { Normal... } \\
\text { Ceniza.... }\end{array}$ & 981 & $\begin{array}{r}922 \\
59 \\
\end{array}$ & $\begin{array}{r}919.69 \\
61.31 \\
\end{array}$ & $15: 1$ & 2.31 & 5.11 & 0.45 \\
\hline Kon $\mathrm{x} \mathrm{Ce}-\mathrm{A} \ldots . .$. & $\begin{array}{l}\text { Normal.... } \\
\text { Ceniza.... }\end{array}$ & 138 & $\begin{array}{r}128 \\
10\end{array}$ & $\begin{array}{r}129.38 \\
8.62 \\
\end{array}$ & $15: 1$ & 1.38 & 1.92 & 0.72 \\
\hline $\mathrm{Kon} x \mathrm{Ce}-\mathrm{B} \ldots \ldots$ & $\begin{array}{l}\text { Normal.... } \\
\text { Ceniza.... }\end{array}$ & 181 & $\begin{array}{r}167 \\
14 \\
\end{array}$ & $\begin{array}{r}169.69 \\
11.31 \\
\end{array}$ & $15: 1$ & 2.69 & 2.20 & 1. 22 \\
\hline $45 \times \mathrm{T} \ldots \ldots$. & $\begin{array}{l}\text { Normal.... } \\
\text { Ceniza.... } \\
\end{array}$ & 85 & $\begin{array}{r}81 \\
4 \\
\end{array}$ & $\begin{array}{r}79.69 \\
5.31\end{array}$ & $15: 1$ & 1.31 & 1.51 & 0.87 \\
\hline $\mathrm{T} \times 45-\mathrm{A} \ldots$. & $\begin{array}{l}\text { Normal.... } \\
\text { Ceniza.... }\end{array}$ & 246 & $\begin{array}{r}229 \\
17\end{array}$ & $\begin{array}{r}230.62 \\
15.38\end{array}$ & $15: 1$ & 1.62 & 2.56 & 0.63 \\
\hline $\mathrm{T} \times 45-\mathrm{B} \ldots \ldots \ldots$ & $\begin{array}{l}\text { Normal... } \\
\text { Ceniza.... }\end{array}$ & 210 & $\begin{array}{r}199 \\
11 \\
\end{array}$ & $\begin{array}{r}196.87 \\
13.12 \\
\end{array}$ & $15: 1$ & 2.12 & 2.37 & 090 \\
\hline $\mathrm{T} \times \mathrm{Ce} \ldots . . . . . .$. & $\begin{array}{l}\text { Normal.... } \\
\text { Ceniza.... } \\
\end{array}$ & 292 & $\begin{array}{r}266 \\
26 \\
\end{array}$ & $\begin{array}{r}273.75 \\
18.25 \\
\end{array}$ & $15: 1$ & 7.75 & 2.69 & 2.88 \\
\hline$(\mathrm{T} \times \mathrm{Ce}) \times \mathrm{Ce} \ldots \ldots$ & $\begin{array}{l}\text { Normal.... } \\
\text { Ceniza.... }\end{array}$ & 379 & $\begin{array}{l}274 \\
105 \\
\end{array}$ & $\begin{array}{r}284.25 \\
94.75 \\
\end{array}$ & $3: 1$ & 10.25 & 5.69 & 1.80 \\
\hline$(\mathrm{Kon} \times \mathrm{Ce}) \mathrm{x} \mathrm{Ce} .$. & $\begin{array}{l}\text { Normal.... } \\
\text { Ceniza.... } \\
\end{array}$ & 317 & $\begin{array}{r}251 \\
66 \\
\end{array}$ & $\begin{array}{r}237.75 \\
79.25 \\
\end{array}$ & $3: 1$ & 13.25 & 5.20 & 2.55 \\
\hline$(45 \times \mathrm{T}) \times 45 \ldots \ldots$ & $\begin{array}{l}\text { Normal... } \\
\text { Ceniza.... }\end{array}$ & 66 & $\begin{array}{l}53 \\
13 \\
\end{array}$ & $\begin{array}{l}49.50 \\
16.50 \\
\end{array}$ & $3: 1$ & 3.50 & 2.37 & 1.48 \\
\hline$(\mathrm{T} \times 45) \times 45 \ldots \ldots$ & $\begin{array}{l}\text { Normal... } \\
\text { Ceniza.... }\end{array}$ & 175 & $\begin{array}{r}138 \\
37\end{array}$ & $\begin{array}{r}131.25 \\
43.75\end{array}$ & $3: 1$ & 6.75 & 3.86 & 1.75 \\
\hline
\end{tabular}


458 THE JOURNAL OF AGRICULTURE OF THE UNIVERSITY OF $P$. $\mathbf{R}$.

TABLE VI

BEHAVIOR OF THE $\mathrm{F}_{3}$ PROGENIES OF THE CROSS $C e \times k O n$ IN THE STUDY OF THE CENIZA OR GLAUCOUS CHARACTER

\begin{tabular}{|c|c|c|c|c|c|c|c|c|}
\hline \multirow{3}{*}{ Progeny } & \multirow{3}{*}{ Color } & \multirow{3}{*}{$\mathrm{n}$} & \multicolumn{3}{|c|}{ Frequencies } & \multirow{3}{*}{ Dev. } & \multirow{3}{*}{ P. E. } & \multirow{3}{*}{ D/P. E, } \\
\hline & & & \multirow[b]{2}{*}{ Observed } & \multicolumn{2}{|c|}{ Calculated } & & & \\
\hline & & & & $\mathrm{n}$ & ratio & & & \\
\hline $17 \ldots \ldots \ldots \ldots \ldots \ldots \ldots$ & $\begin{array}{l}\text { Normal.... } \\
\text { Ceniza.... }\end{array}$ & 137 & $\begin{array}{r}133 \\
4\end{array}$ & $\begin{array}{r}128.440 \\
8.560\end{array}$ & $15: 1$ & 4.560 & 1.91 & 2.39 \\
\hline $18, \ldots \ldots \ldots \ldots \ldots \ldots$ & $\begin{array}{l}\text { Normal... } \\
\text { Ceniza.... }\end{array}$ & 34 & $\begin{array}{r}31 \\
3\end{array}$ & $\begin{array}{r}31.880 \\
2.120\end{array}$ & $15: 1$ & 0.880 & 0.95 & 0.93 \\
\hline $19 \ldots \ldots \ldots \ldots \ldots \ldots$ & $\begin{array}{l}\text { Normal.... } \\
\text { Ceniza.... }\end{array}$ &, 55 & $\begin{array}{r}51 \\
4 \\
\end{array}$ & $\begin{array}{r}51.560 \\
3.440 \\
\end{array}$ & $15: 1$ & 0.560 & 1.21 & 0.46 \\
\hline $23 \ldots \ldots \ldots \ldots \ldots \ldots$ & $\begin{array}{l}\text { Normal.... } \\
\text { Ceniza.... }\end{array}$ & 130 & $\begin{array}{r}122 \\
8\end{array}$ & $\begin{array}{r}121.875 \\
8.125\end{array}$ & $15: 1$ & 0.125 & 1.86 & 0.07 \\
\hline $30 \ldots \ldots \ldots \ldots \ldots \ldots$ & $\begin{array}{l}\text { Normal... } \\
\text { Ceniza.... }\end{array}$ & 120 & $\begin{array}{r}114 \\
6 \\
\end{array}$ & $\begin{array}{r}112.500 \\
7.500\end{array}$ & $15: 1$ & 1.500 & 1.79 & 0.84 \\
\hline $40 \ldots \ldots$ & $\begin{array}{l}\text { Normal.... } \\
\text { Ceniza.... }\end{array}$ & 128 & $\begin{array}{r}122 \\
6\end{array}$ & $\begin{array}{r}120.000 \\
8.000\end{array}$ & $15: 1$ & 2.000 & 1.85 & 1.08 \\
\hline $42 \ldots \ldots \ldots \ldots \ldots \ldots$ & $\begin{array}{l}\text { Normal.... } \\
\text { Ceniza.... } \\
\end{array}$ & 128 & $\begin{array}{r}123 \\
5 \\
\end{array}$ & $\begin{array}{r}120.000 \\
8.000\end{array}$ & $15: 1$ & 3.000 & 1.85 & 1.62 \\
\hline $5 \ldots \ldots \ldots$ & $\begin{array}{l}\text { Normal.... } \\
\text { Ceniza.... }\end{array}$ & 246 & $\begin{array}{r}181 \\
65 \\
\end{array}$ & $\begin{array}{r}184.500 \\
61.500 \\
\end{array}$ & $3: 1$ & 3.500 & 4.58 & 0.76 \\
\hline $6 \ldots$. & $\begin{array}{l}\text { Normal... } \\
\text { Ceniza.... }\end{array}$ & 175 & $\begin{array}{r}138 \\
37\end{array}$ & $\begin{array}{r}131.250 \\
43.750\end{array}$ & $3: 1$ & 6.750 & 3.86 & 1.75 \\
\hline $7 \ldots \ldots \ldots \ldots \ldots \ldots$ & $\begin{array}{l}\text { Normal.... } \\
\text { Ceniza.... }\end{array}$ & 153 & $\begin{array}{r}111 \\
42\end{array}$ & $\begin{array}{r}114.750 \\
38.250\end{array}$ & $3: 1$ & 3.750 & 3.61 & 1.04 \\
\hline $16 \ldots \ldots \ldots \ldots \ldots \ldots$ & $\begin{array}{l}\text { Normal... } \\
\text { Ceniza.... }\end{array}$ & 153 & $\begin{array}{r}141 \\
12\end{array}$ & $\begin{array}{r}143.440 \\
9.560\end{array}$ & $3: 1$ & 2.440 & 3.61 & 0.68 \\
\hline $25 \ldots \ldots \ldots \ldots \ldots \ldots$ & $\begin{array}{l}\text { Normal.... } \\
\text { Ceniza.... }\end{array}$ & 120 & $\begin{array}{l}94 \\
26\end{array}$ & $\begin{array}{l}90.000 \\
30.000\end{array}$ & $3: 1$ & 4.000 & 3.20 & 1.25 \\
\hline $32, \ldots \ldots \ldots \ldots \ldots \ldots$ & $\begin{array}{l}\text { Normal... } \\
\text { Ceniza.... }\end{array}$ & 120 & $\begin{array}{l}96 \\
24\end{array}$ & $\begin{array}{l}90.000 \\
30.000\end{array}$ & $3: 1$ & 6.000 & 3.20 & 1.87 \\
\hline
\end{tabular}

Families breeding true to normal: $4,9,15,26$ and 33 .

Families breeding true to "Ceniza" or glaucous: 39 and 43 . 
TABLE VII

BEHAVIOR OF THE $\mathrm{F}_{3}$ PROGENIES OF THE CROSS $K O N \times C E$ IN THE STUDY OF THE CENIZA OR GLAUCOUS CHARACTER

\begin{tabular}{|c|c|c|c|c|c|c|c|c|}
\hline \multirow{3}{*}{ Progeny } & \multirow{3}{*}{ Color } & \multirow{3}{*}{$\mathrm{n}$} & \multicolumn{3}{|c|}{ Frequencies } & \multirow{3}{*}{ Dev. } & \multirow{3}{*}{ P. E. } & \multirow{3}{*}{ D/P. E. } \\
\hline & & & \multirow{2}{*}{ Observed } & \multicolumn{2}{|c|}{ Calculated } & & & \\
\hline & & & & $\mathrm{n}$ & ratio & & & \\
\hline $55 \ldots \ldots \ldots \ldots \ldots \ldots$ & $\begin{array}{l}\text { Normal.... } \\
\text { Ceniza.... }\end{array}$ & 365 & $\begin{array}{r}334 \\
31\end{array}$ & $\begin{array}{r}342.19 \\
22.81\end{array}$ & $15: 1$ & 8.19 & 3.12 & 2.62 \\
\hline $62 \ldots \ldots \ldots \ldots \ldots \ldots$ & $\begin{array}{l}\text { Normal... } \\
\text { Ceniza.... }\end{array}$ & 282 & $\begin{array}{r}264 \\
18\end{array}$ & $\begin{array}{r}264.32 \\
17.62\end{array}$ & $15: 1$ & 0.37 & 2.74 & 0.14 \\
\hline $65 \ldots \ldots \ldots \ldots \ldots \ldots$ & $\begin{array}{l}\text { Normal... } \\
\text { Ceniza.... }\end{array}$ & 311 & $\begin{array}{r}299 \\
12\end{array}$ & $\begin{array}{r}291.56 \\
19.44\end{array}$ & $15: 1$ & 7.44 & 2.88 & 2.58 \\
\hline $66 \ldots \ldots \ldots \ldots \ldots \ldots \ldots$ & $\begin{array}{l}\text { Normal.... } \\
\text { Ceniza.... }\end{array}$ & 448 & $\begin{array}{r}421 \\
27\end{array}$ & $\begin{array}{r}420.00 \\
28.00\end{array}$ & $15: 1$ & 1.00 & 3.46 & 0.29 \\
\hline $71 \ldots \ldots \ldots \ldots \ldots \ldots$ & $\begin{array}{l}\text { Normal... } \\
\text { Ceniza.... }\end{array}$ & 308 & $\begin{array}{r}281 \\
27\end{array}$ & $\begin{array}{r}288.75 \\
19.25\end{array}$ & $15: 1$ & 7.75 & 2.87 & 2.70 \\
\hline $85 \ldots \ldots \cdots \cdots \cdots \cdots$ & $\begin{array}{l}\text { Normal... } \\
\text { Ceniza.... }\end{array}$ & 286 & $\begin{array}{r}268 \\
18\end{array}$ & $\begin{array}{r}268.13 \\
17.87\end{array}$ & $15: 1$ & 0.13 & 2.76 & 0.05 \\
\hline $91 \ldots \ldots \ldots \ldots \ldots \ldots$ & $\begin{array}{l}\text { Normal... } \\
\text { Ceniza.... } \\
\end{array}$ & $\begin{array}{r}149 \\
\ldots \cdots \\
\end{array}$ & $\begin{array}{r}142 \\
7\end{array}$ & $\begin{array}{r}139.69 \\
9.31\end{array}$ & $15: 1$ & 2.31 & 1.99 & 1.16 \\
\hline $52 \ldots \ldots \ldots \ldots \ldots \ldots \ldots$ & $\begin{array}{l}\text { Normal... } \\
\text { Ceniza.... }\end{array}$ & 401 & $\begin{array}{r}319 \\
82\end{array}$ & $\begin{array}{l}300.75 \\
100.25\end{array}$ & $3: 1$ & 18.25 & 5.85 & 3.12 \\
\hline $58 \ldots \ldots \ldots \ldots \ldots \ldots$ & $\begin{array}{l}\text { Normal... } \\
\text { Ceniza.... }\end{array}$ & 327 & $\begin{array}{r}258 \\
69\end{array}$ & $\begin{array}{r}245.25 \\
81.75\end{array}$ & $3: 1$ & 12.75 & 5.28 & 2.41 \\
\hline $67 \ldots \ldots \ldots \ldots \ldots \ldots$ & $\begin{array}{l}\text { Normal... } \\
\text { Ceniza.... }\end{array}$ & 380 & $\begin{array}{r}287 \\
93\end{array}$ & $\begin{array}{r}285.00 \\
95.00\end{array}$ & $3: 1$ & 2.00 & 5.69 & 0.35 \\
\hline $68 \ldots \ldots \ldots \ldots \ldots \ldots$ & $\begin{array}{l}\text { Normal... } \\
\text { Ceniza.... }\end{array}$ & 406 & $\begin{array}{r}313 \\
93\end{array}$ & $\begin{array}{l}304.50 \\
101.50\end{array}$ & $3: 1$ & 8.50 & 5.88 & 1.45 \\
\hline $76 \ldots \ldots \ldots \ldots \ldots \ldots$ & $\begin{array}{l}\text { Normal... } \\
\text { Ceniza.... }\end{array}$ & 198 & $\begin{array}{r}155 \\
43\end{array}$ & $\begin{array}{r}148.50 \\
49.50\end{array}$ & $3: 1$ & 6.50 & 4.11 & 1.58 \\
\hline $83 \ldots \ldots \ldots \ldots \ldots$ & $\begin{array}{l}\text { Normal... } \\
\text { Ceniza.... }\end{array}$ & 252 & $\begin{array}{r}201 \\
51\end{array}$ & $\begin{array}{r}18900 \\
63.00\end{array}$ & $3: 1$ & 12.00 & 4.64 & 2.59 \\
\hline
\end{tabular}

Families breeding true to normal: $53,57,60,63,64,69,70,72,77,78,79,89$ and 90.

Families breeding true to "Ceniza": 59 and 61 . 
TABLE VIII

SHOWING PHENOTYPIC DISTRIBUTION IN $\mathrm{F}_{2}, \mathrm{~F}_{3}$ AND B. C. PROGENIES OF CROSSES IN THE STUDY OF THE YELLOW AND CENIZA CHARACTERS

\begin{tabular}{|c|c|c|c|c|c|c|}
\hline \multirow{3}{*}{ Progeny } & \multirow{3}{*}{ Class * } & \multicolumn{3}{|c|}{ Frequencies } & \multirow{3}{*}{$\begin{array}{l}\text { Chi } \\
\text { Square }\end{array}$} & \multirow{3}{*}{$\mathrm{P}$} \\
\hline & & \multirow{2}{*}{ Observed } & \multicolumn{2}{|c|}{ Calculated } & & \\
\hline & & & ratio & $\mathrm{n}$ & & \\
\hline Ce $x$ Kon - C............... & $\begin{array}{l}\text { NY } \ldots \ldots \ldots \\
\text { Ny } \ldots \ldots \ldots . . . \\
\text { nY......... } \\
\text { ny } \ldots \ldots \ldots \\
\text { Total ...... }\end{array}$ & $\begin{array}{r}703 \\
230 \\
43 \\
21 \\
997 \\
\end{array}$ & $\begin{array}{r}45 \\
15 \\
3 \\
1 \\
\\
\end{array}$ & $\begin{array}{r}701.0160 \\
233.6720 \\
46.7340 \\
15.5780 \\
997.0000 \\
\end{array}$ & $=2.24376$ & 0.53 \\
\hline Ce $\mathrm{x}$ Kon $-\mathrm{D} \ldots \ldots \ldots \ldots$ & $\begin{array}{l}\text { NY } \ldots \ldots \ldots \\
\text { Ny } \ldots \ldots \ldots . \\
\text { nY........... } \\
\text { ny } \ldots \ldots \ldots \\
\text { Total } \ldots . . .\end{array}$ & $\begin{array}{r}693 \\
229 \\
41 \\
18 \\
981 \\
\end{array}$ & $\begin{array}{r}45 \\
15 \\
3 \\
1 \\
\end{array}$ & $\begin{array}{r}689.7660 \\
229.9220 \\
45.9840 \\
15.3280 \\
981.0000 \\
\end{array}$ & $=1.02484$ & 0.80 \\
\hline $\mathrm{Kon} \mathrm{x} \mathrm{Ce}-\mathrm{A} \ldots \ldots \ldots \ldots$ & 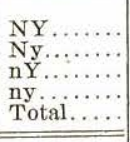 & $\begin{array}{r}100 \\
28 \\
9 \\
1 \\
138\end{array}$ & $\begin{array}{r}45 \\
15 \\
3 \\
1 \\
\cdots \cdots \\
\end{array}$ & $\begin{array}{r}97.0310 \\
32.3440 \\
6.4688 \\
2.1562 \\
138.0000\end{array}$ & $=2.28431$ & 0.52 \\
\hline Ce $x$ Kon $-6 \ldots \ldots \ldots \ldots$ & $\begin{array}{l}\mathrm{NY} \ldots \ldots \ldots \\
\mathrm{Ny} \ldots \ldots \ldots \\
\text { nY........... } \\
\text { ny } \ldots \ldots \ldots \\
\text { Total...... }\end{array}$ & $\begin{array}{r}94 \\
44 \\
29 \\
8 \\
175 \\
\end{array}$ & $\begin{array}{r}9 \\
3 \\
3 \\
1 \\
\cdots \\
\end{array}$ & $\begin{array}{r}98.4375 \\
32.8125 \\
32.8125 \\
10.9375 \\
175.0000 \\
\end{array}$ & $=5.24636$ & 0.16 \\
\hline Ce $x$ Kon-7.............. & $\begin{array}{l}\text { NY } \ldots \ldots \ldots \\
\text { Ny.......... } \\
\text { nY.......... } \\
\text { ny........ } \\
\text { Total..... }\end{array}$ & $\begin{array}{r}81 \\
30 \\
35 \\
7 \\
153 \\
\end{array}$ & $\begin{array}{r}9 \\
3 \\
3 \\
1 \\
\cdots\end{array}$ & $\begin{array}{r}86.0625 \\
28.6875 \\
28.6875 \\
9.5625 \\
153.0000 \\
\end{array}$ & $=2.43355$ & 0.49 \\
\hline Ce $x$ Kon- $30 . . . \ldots \ldots \ldots$ & $\begin{array}{l}\text { NY } \ldots \ldots . . \\
\text { Ny } \ldots \ldots \ldots \\
\text { nY......... } \\
\text { ny........ } \\
\text { Total..... }\end{array}$ & $\begin{array}{r}49 \\
8 \\
2 \\
1 \\
60\end{array}$ & $\begin{array}{r}45 \\
15 \\
3 \\
1 \\
\cdots\end{array}$ & $\begin{array}{r}42.1875 \\
14.0625 \\
2.8125 \\
0.9375 \\
60.0000\end{array}$ & $=3.95250$ & 0.27 \\
\hline $\mathrm{Kon} \times \mathrm{Ce}-55 \ldots \ldots \ldots \ldots$ & $\begin{array}{l}\text { NY } \ldots \ldots \ldots \\
\text { Ny.......... } \\
\text { nY.......... } \\
\text { ny......... } \\
\text { Total..... }\end{array}$ & $\begin{array}{r}226 \\
119 \\
12 \\
8 \\
365\end{array}$ & $\begin{array}{r}45 \\
15 \\
3 \\
1 \\
\cdots\end{array}$ & $\begin{array}{r}256.6410 \\
85.5470 \\
17.1090 \\
5.7030 \\
365.0000\end{array}$ & $=19.19081$ & 0.0003 \\
\hline Kon $\mathrm{x} \mathrm{Ce}-62, \ldots \ldots \ldots \ldots$ & $\begin{array}{l}\text { NY } \ldots \ldots \ldots \\
\text { Ny.......... } \\
\text { nY......... } \\
\text { ny........ } \\
\text { Total..... }\end{array}$ & $\begin{array}{r}196 \\
68 \\
12 \\
6 \\
282\end{array}$ & $\begin{array}{r}45 \\
15 \\
3 \\
1 \\
\ldots \ldots \\
\end{array}$ & $\begin{array}{r}198.2810 \\
66.0940 \\
13.2190 \\
4.4060 \\
282.0000\end{array}$ & $=1.26496$ & 0.74 \\
\hline $\mathrm{Kon} \mathrm{x} \mathrm{Ce}-66 \ldots \ldots \ldots \ldots$ & $\begin{array}{l}\text { NY } \ldots \ldots \ldots \\
\text { Ny.............. } \\
\text { nY. } \ldots \ldots \ldots \\
\text { ny......... } \\
\text { Total..... }\end{array}$ & $\begin{array}{r}322 \\
99 \\
22 \\
5 \\
448\end{array}$ & $\left|\begin{array}{r}45 \\
15 \\
3 \\
1 \\
\cdots\end{array}\right|$ & $\begin{array}{r}315.0000 \\
105.0000 \\
21.0000 \\
7.0000 \\
448.0000\end{array}$ & $=1.11746$ & 0.77 \\
\hline
\end{tabular}

*The class $N Y$ stands for normal green, $N y$ is normal yellow, $n Y$ is ce, or glaucous green, and $n y$ represents ce yellow. 
TABI.E VIII-(Cont.)

SHOWING PHENOTYPIC DISTRIBUTION IN F $\mathrm{F}_{2}, \mathrm{~F}_{3}$ AND B. C. PROGENIES OF CROSSES IN THE STUDY OF THE YELLOW AND CENIZA CHARACTERS

\begin{tabular}{|c|c|c|c|c|c|c|}
\hline \multirow{3}{*}{ Progeny } & \multirow{3}{*}{ Class * } & \multicolumn{3}{|c|}{ Frequencies } & \multirow{3}{*}{$\begin{array}{l}\text { Chi } \\
\text { Square }\end{array}$} & \multirow{3}{*}{$\mathrm{P}$} \\
\hline & & \multirow{2}{*}{ Observed } & \multicolumn{2}{|c|}{ Calculated } & & \\
\hline & & & ratio & $\mathrm{n}$ & & \\
\hline Kon $\mathrm{x} \mathrm{Ce}-71 \ldots \ldots \ldots \ldots$ & $\begin{array}{l}\text { NY } \ldots \ldots \ldots \\
\text { Ny......... } \\
\text { nY. } \ldots \ldots \ldots \\
\text { ny } \ldots \ldots \ldots \\
\text { Total } \ldots \ldots\end{array}$ & $\begin{array}{r}217 \\
64 \\
22 \\
5 \\
308\end{array}$ & $\begin{array}{r}45 \\
15 \\
3 \\
1 \\
1 \\
\end{array}$ & $\begin{array}{r}216.5620 \\
72.1870 \\
14.4380 \\
4.8130 \\
308.0000\end{array}$ & $=4.89732$ & 0.18 \\
\hline $\mathrm{Kon} \times \mathrm{Ce}-85 \ldots$ & $\begin{array}{l}\text { NY } \ldots \ldots \ldots \\
\text { Ny } \ldots \ldots \ldots . \\
\text { nY......... } \\
\text { ny } \ldots \ldots \ldots \\
\text { Total } \ldots . . .\end{array}$ & $\begin{array}{r}186 \\
82 \\
13 \\
5 \\
286\end{array}$ & $\begin{array}{r}45 \\
15 \\
3 \\
1 \\
1 \\
\ldots .\end{array}$ & $\begin{array}{r}201.0940 \\
67.0310 \\
13.4060 \\
4.4690 \\
286.0000\end{array}$ & $=4.55113$ & 0.21 \\
\hline $\mathrm{Kon} \mathrm{x} \mathrm{Ce}-52 \ldots \ldots \ldots$ & $\begin{array}{l}\text { NY } \ldots \ldots \ldots \\
\text { Ny } \ldots \ldots \ldots \\
\text { nY } \ldots \ldots \ldots \\
\text { ny } \ldots \ldots \ldots \\
\text { Total } \ldots \ldots\end{array}$ & $\begin{array}{r}223 \\
96 \\
59 \\
23 \\
401\end{array}$ & $\begin{array}{r}9 \\
3 \\
3 \\
3 \\
1 \\
\cdots\end{array}$ & $\begin{array}{r}225.5620 \\
75.1870 \\
75.1880 \\
25.0630 \\
401.0000\end{array}$ & $=9.44557$ & 0.24 \\
\hline $\mathrm{Kon} \times \mathrm{Ce}-67 \ldots$ & 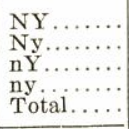 & $\begin{array}{r}207 \\
80 \\
72 \\
21 \\
380\end{array}$ & $\begin{array}{l}9 \\
3 \\
3 \\
1\end{array}$ & $\begin{array}{r}213.7500 \\
71.2500 \\
71.2500 \\
23.7500 \\
380.0000\end{array}$ & $=1.61403$ & 0.66 \\
\hline Kon $\mathrm{x} \mathrm{Ce}-68 \ldots \ldots$ & 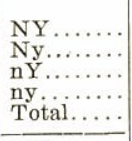 & $\begin{array}{r}239 \\
74 \\
79 \\
14 \\
405\end{array}$ & $\begin{array}{r}9 \\
3 \\
3 \\
1 \\
1 \\
\end{array}$ & $\begin{array}{r}228.3750 \\
76.1250 \\
76.1250 \\
25.3750 \\
406.0000\end{array}$ & $=5.76136$ & 0.13 \\
\hline Kon $\mathrm{x} \mathrm{Ce}-76 \ldots \ldots \ldots \ldots$ & 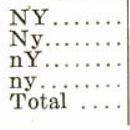 & $\begin{array}{r}123 \\
32 \\
31 \\
12 \\
193\end{array}$ & $\begin{array}{r}9 \\
3 \\
3 \\
3 \\
1 \\
r \cdots\end{array}$ & $\begin{array}{r}111.3750 \\
37.1250 \\
37.1250 \\
12.3750 \\
198.0000\end{array}$ & $=2.94275$ & 0.40 \\
\hline
\end{tabular}


462 THE JOURNAL OF AGRICULTURE OF THE UNIVERSITY OF P. R.

TABLE IX

BEHAVIOR OF GENOTYPES IN RELATION TO THE CE CHARACTER OR ITS ALLELOMORPH IN F 3 FAMILIES WHICH ARE PURE BREEDING FOR. GREEN OR SEGREGATING FOR GREEN AND YELLOW

\begin{tabular}{|c|c|c|c|c|c|c|}
\hline \multirow{2}{*}{ Class } & & \multirow{2}{*}{$\begin{array}{l}\text { Calculated } \\
\text { ratio }\end{array}$} & \multicolumn{2}{|c|}{$\mathrm{n}$} & \multirow{2}{*}{$\begin{array}{c}\text { Chi } \\
\text { Square }\end{array}$} & \multirow{2}{*}{$\mathrm{P}$} \\
\hline & & & Observed & Calculated & & \\
\hline \multirow[t]{5}{*}{ Green $\ldots \ldots \ldots \ldots \ldots \ldots \ldots$} & Normal... & 7 & 6 & 5.250 & & \\
\hline & $15: 1 \ldots \ldots$ & 4 & 2 & 3.000 & & \\
\hline & $3: 1 \ldots \ldots \ldots$ & 4 & 3 & 3.000 & & \\
\hline & ce......... & 1 & $1 \cdot$ & 0.750 & & \\
\hline & Total..... & 16 & 12 & 12.000 & $=0.52380$ & Over 0.80 \\
\hline \multirow[t]{5}{*}{ Segregating Green \& Yellow } & Normal... & 14 & 11 & 11.375 & & \\
\hline & $15: 1 \ldots \ldots$ & 8 & 6 & 6.500 & & \\
\hline & $3: 1 \ldots \ldots \ldots$ & 8 & 8 & 6.500 & & \\
\hline & ce......... & 2 & 1 & 1.625 & & \\
\hline & Total..... & 32 & 26 & 26.000 & $=0.63734$ & Over 0.80 \\
\hline
\end{tabular}

